\title{
Decreasing of Environmental Loads in Tapioca Industry Through Utilization of Biogas Digester Effluent for Fertigation During Vegetables Production
}

\author{
J R Amelia ${ }^{1}$ O Maulidia ${ }^{2}$ A Haryanto ${ }^{3, *}$ S Triyono $^{3}$ U Hasanudin $^{4}$
}

\author{
${ }^{I}$ Department of Food Technology, Universitas Sahid, Jakarta, Indonesia \\ ${ }^{2}$ Department of Environmental Science, Universitas Lampung, Bandar Lampung, Indonesia \\ ${ }^{3}$ Department of Agricultural Engineering, Universitas Lampung, Bandar Lampung, Indonesia \\ ${ }^{4}$ Department of Agro-Industrial Technology, Universitas Lampung, Bandar Lampung, Indonesia \\ *Corresponding author. Email: agus.haryanto@fp.unila.ac.id
}

\begin{abstract}
In order to lower environmental burden, a tapioca industry make use its wastewater to generate biogas through anaerobic digestion process using a covered lagoon system. However, the effluent from the digester still has not met the quality standards so that it cannot be disposed into the water body. Organic matter remaining in the digester effluent is expected to be used as a source of plant nutrients through fertigation. The purpose of this study was to calculate the reduction potential of environment load th rough the utilization of wastewater effluent from the tapioca wastewater biogas digester and determine the fertigation dose of wastewater addition during vegetable cultivation on soil media. Completely randomized design was used in this experimental with two factors, namely plant type(T) as first factor consisting of $\mathrm{T} 1=$ pakcoy, $\mathrm{T} 2=$ water spinach, $\mathrm{T} 3=$ tomato, and $\mathrm{T} 4=$ cucumber, and fertigation rate (in term of available water level) as the second factor consisting of $\mathrm{K} 1=100-81 \%, \mathrm{~K} 2=80-61 \%, \mathrm{~K} 3=60-41 \%$, $\mathrm{K} 4=40-21 \%$ of available water. The experiment was carried out with three replications and no chemical fertilizer was added. Results showed that water spinach and pakcoy have a higher potential in reducing COD, nitrogen, phosphorus, and potassium as compared to tomatoes and cucumbers. Results also showed that cultivation of pakcoy with available soil water $81 \%-100 \%$ (T1K1) was able to decrease environmental load of $7,47 \%$, water spinach with soil water $61 \%$ $80 \%$ (T2K2) reduced the load by $8,26 \%$, tomato with soil water41\%-60\% (T3K3) reduced the load by $6,43 \%$, and cucumber with soil water $81 \%-100 \%$ (T4K4) reduced the load by $4,54 \%$.
\end{abstract}

Keywords: Tapioca, Biogas, Digester, Fertigation, Vegetable Production

\section{INTRODUCTION}

Tapioca flour is the main cassava derivative used for feed and is widely processed in Lampung Province, Indonesia, with contribution more than $30 \%$ [1]. Cassava processing for tapioca produces large amounts of wastewater. The wastewater is generated in the proportion of $20 \mathrm{~m} 3$ for each ton of tapioca flour or 5 m3for each ton of cassava root [2]. It is highly contain of organic matter. The main characteristics of the cassava wastewater are $\mathrm{pH} 4.50-4.92$, total suspended solids (TSS) $827 \mathrm{mg} / \mathrm{L}$, chemical oxygen demand (COD) $10,496 \mathrm{mg} / \mathrm{L}$ and biological oxygen demand (BOD)
$6300 \mathrm{mg} / \mathrm{L}[3]$. We also found similar COD value of tapioca wastewater, that is $9,647.5 \mathrm{mg} / \mathrm{L}$ in average [4]. The wastewater also contains valuable nutrients, such as nitrogen, phosphorus, potassium, calcium, magnesium, etc. Total nitrogen and total phosporus of tapioca wastewater is about $524.5 \mathrm{mg} / \mathrm{L}$ and $94 \mathrm{mg} / \mathrm{L}$, respectively [3].

High organic content in the wastewater has negative impacts on the environment so that it need to be treated. Anaerobic digestion is a cost-effective way of treating wastewater with high organic content, as it efficiently removes large amounts of organics and at the same time 
produces biogas as clean fuel. Anaerobic digestion process produces clean biogas fuel that can be used for different applications such as fuel for kitchen stove, fuel for small engine, and generate electricity through gas engine. At the same time, the process also produces a by-product in form of slurry digestate that offers quality biofertilizer to replace chemical fertilizer [5,6]. During anaerobic digestion process, different groups of microorganisms work interactively under condition of no oxygen converting complex organic matter into methane $(\mathrm{CH} 4)$, carbon dioxide $(\mathrm{CO} 2)$, water, hydrogen sulfide $(\mathrm{H} 2 \mathrm{~S})$, ammonia (NH3+), and new bacterial cells [7,8]. Anaerobic treatment of tapioca wastewater has been studied for biogas production [9-11]. Anaerobic digestion has some advantages, such as lower energy need (no aeration needed and possible recovery of biogas), less sludge production due to lower biomass production, fewer nutrients required again due to the lower biomass production and the possible application of higher volumetric loadings leading to possible area requirement reductions [12]. Disadvantages with anaerobic digestion are the longer start-up period, the possible need for alkalinity addition and that the effluent quality is not as good and thus further treatment may be needed [12].

The characteristics of the effluent from anaerobic treatment of tapioca wastewater as follows: $\mathrm{pH}$ 6.47, COD $722.5 \mathrm{mg} / \mathrm{L}$, TSS $388.25 \mathrm{mg} / \mathrm{L}$, nitrogen total $417.2 \mathrm{mg} / \mathrm{L}$, and phosphorus total $18.32 \mathrm{mg} / \mathrm{L}$ [13]. Nitrogen and phosphorus are essential for plant and animal growth and nourishment, but the over-abundance of certain nutrients in water can cause a number of adverse health and ecological effects (eutrophication), so it requires additional treatment before being discharged into the environment. High organic wastewater is potentially used for fertigation (fertilizer and irrigation) for vegetables production. The purpose of this study was to calculate the potential reduction in pollution load through the utilization of effluent originating from the tapioca wastewater biogas digester and determine the dose of fertigation rate during vegetable cultivation on soil media by utilizing the biogas digester effluent in order to reduce the environment load of the wastewater produced from a small-scale tapioca industry.

\section{MATERIAL AND METHODS}

\subsection{MATERIALS}

\subsubsection{Soil}

The soil samples were taken from three points of each plantation land blocks ( 3 blocks) at a depth of $0-$ $5 \mathrm{~cm}$. The soil at a depth of $0-5 \mathrm{~cm}$ is very sensitive to changes that occur on the surface of the soil. Soil samples were sieved to separate soil particle fraction of less than $2 \mathrm{~mm}$ from any gravel or larger detritus. The soil fraction $<2 \mathrm{~mm}$ from each core or composite sample were mixed thoroughly to produce a homogenous sample. Soil samples were then put into plastic sample bags and labeled on each soil sample for analysis of $\mathrm{pH}$, total $\mathrm{C}$ organic, nitrogen total, phosphorus total, and potassium total.

\subsubsection{Digester Effluent}

Wastewater from biogas digester effluent was provided by PD. Semangat Jaya, a small-scale tapioca industry located in Sri Rejeki Village, Subdistrict of Negeri Katon, District of Pesawaran, Lampung Province. The wastewater effluent was used for fertigation water as it is.

\subsection{EXPERIMENTAL METHODS}

The experiment was carried out by using completely randomized design (CRD) of two factors, namely plant types and fertigation rate. Plant type factor consist of four, namely pakcoy (T1), water spinach (T2), tomato (T3), and cucumber (T4); whereas fertigation rate was based on soil water availability and consists of 100-81\% of available water(K1), 80-61\% (K2), 60-41\% (K3), and $40-21 \%$ (K4). All treatment combinations were performed triplicates.

\subsection{CHEMICAL ANALYSIS}

The following parameters for effluent and soil characteristics were analyzed according to APHA standard methods of 1999[14]: pH, Total Suspended Solid (TSS), and Chemical Oxygen Demand( COD). Nitrogen total was determined by Kjeldahl method. Phosphorus total was determined by spectrophotometric method. Potassium total was determined by a flame photometric method. Soil organic carbon was determined according to Walkey and Black [15].

Plant samples were weighed to determine the wet mass of the plant. Furthermore, the sample were put into a paper bag and then heated at $70{ }^{\circ} \mathrm{C}$. After drying, the plant samples are weighed again to determine the moisture content of plants. The next step was grinding the sample using a grinding machine. Milled plant samples are placed on plastic samples and labeled on each plant sample. Samples of the milled plants are then carried out dry ashing using a furnace at $550{ }^{\circ} \mathrm{C}$ for two hours.

\section{RESULTS AND DISCUSSION}

\subsection{SOIL CHARACTERISTICS}

Soil organic matter content is also considered an indicator of soil health. The characteristics of soil in this research are shown in Table 1 . It shows that the soil used in this study had a low fertility, especially the content of total nitrogen and total phosphorus. Nitrogen 
and phosphorus are important nutrients in agricultural soil ecosystems. Both total nitrogen and total phosphorus not only become indicators of soil fertility and quality, but also be the major determinants of soil quality because the relate closely to soil productivity [16]. Nitrogen in the soil plays important roles in the structural component, generic, and metabolic compounds in a plant cell, whereas phosphorous contributes to the complex of the nucleic acid structure of plants [17]. Soil minerals in this research do not release an enough amount of nitrogen and phosphorus to support plant; therefore, fertilizing is necessary for high production.

Table 1. The characteristics of soil used in the experiment

\begin{tabular}{|l|c|c|}
\hline \multicolumn{1}{|c|}{ Parameter } & Value & Criteria \\
\hline $\mathrm{pH}$ & 4.60 & Acid \\
\hline $\mathrm{C} \mathrm{( \% )}$ & 1.39 & Low \\
\hline Nitrogen total (mg/L) & 0.14 & Low \\
\hline Phosphorus total (mg/L) & 0.0078 & Low \\
\hline C/N & 9.92 & Low \\
\hline Potassium total (mg/L) & 20.39 & Low \\
\hline $\begin{array}{l}\text { Total Suspended Solid } \\
\text { (TSS) mg/L }\end{array}$ & 0.020 & Low \\
\hline
\end{tabular}

\subsection{DIGESTER EFFLUENT CHARACTERISTICS}

The effluent used for fertigation in this experimentation was resulted from anaerobic treatment of cassava starch wastewater. The characteristics of effluent are shown in Table2 showing that $\mathrm{pH}$ of effluent is 7.80 (about neutral condition). With the presence of organic nitrogen compounds, the effluent composition is expected to have contribution in increasing soil $\mathrm{pH}$ value (from acid to neutral) due to bicarbonate alkalinity. Bicarbonate that can be produced from the anaerobic decomposition of organic nitrogen compounds derived from wastewater, is the main source of buffer capacity in the neutral $\mathrm{pH}$ [18].

Table 1 also shows that effluents have high levels of nitrogen, potassium, and phosphorus. The content of nitrogen, potassium, and phosphorus in effluents can be a nutrient pollution called as eutrophication. Nutrient pollution occurs where high amount nutrients, especially nitrogen and phosphorus, are added to the water bodies that act in gas fertilizer and causing excessive growth of plant, algae, etc. This condition may lead to cause eutrophication, amore detrimental problems, in which excessive nutrients stimulate algal bloomso that oxygen dissolved in the water is very low andcausing deadly conditions for fish and other aquatic animals[19].

Table 2. The characteristics of effluent used for fertigation

\begin{tabular}{|l|c|}
\hline \multicolumn{1}{|c|}{ Parameter } & Value \\
\hline $\mathrm{pH}$ & 7.80 \\
\hline $\begin{array}{l}\text { Chemical Oxygen Demand (COD) } \\
(\mathrm{mg} / \mathrm{L})\end{array}$ & 260 \\
\hline Nitrogen total (mg/L) & 121.93 \\
\hline Phosphorus total (mg/L) & 27.80 \\
\hline Potassium total (mg/L) & 20.39 \\
\hline Total Suspended Solid (TSS) $\mathrm{mg} / \mathrm{L}$ & 0.20 \\
\hline
\end{tabular}

\subsection{THE EFFETC OF TREATMENT ON SOIL CONDITIONS}

The effect of plant type and fertigation rate treatments on soil conditions are shown in Table 3. It shows that $\mathrm{pH}$ of soil increased from 4.60 (before treatment) to 4.60-5.50 after treatment, indicating that the treatment can increase $\mathrm{pH}$ of the soil. Low soil $\mathrm{pH}$ indicates the presence of more hydrogen ions, which makes a substance more acidic. Soils turn to acidic when basic elements such as calcium $(\mathrm{Ca})$, magnesium $(\mathrm{Mg})$, sodium $(\mathrm{Na})$, and potassium $(\mathrm{K})$ which are gripped by soil colloids are replaced by hydrogen ions [20]. The optimal $\mathrm{pH}$ range for most plants is between 5.5 and 7.0; however, many plants have adapted to strive at $\mathrm{pH}$ values outside this range.

The results showed that fertigation treatment of plant species had a significantly different effect on soil $\mathrm{pH}$ values, whereas the treatment of soil water availability by applying effluent did not have a significant effect on soil $\mathrm{pH}$. The results also showed that the interaction of the two treatment factors (plant type and soil water availability) did not have a significantly different effect on soil $\mathrm{pH}$ conditions.Table 3 also reveals that the organic $\mathrm{C}$ content of the soil increases after the experiment. The organic $\mathrm{C}$ content of the soil before treatment is only about $1.39 \%$. After treatment, organic $\mathrm{C}$ content increased to $1.61-1.78 \%$ in pakcoy plants, $1.68-1.77 \%$ in water spinach plants, $1.35-1.51 \%$ in tomato plants, and 1.61-1.78 \% in cucumber plants. Results of the analysis of variance showed that plant species had a significantly different effect on organic C content in the soil, but the fertigation treatment by applying effluent did not have a significantly different effect on organic $\mathrm{C}$ conditions. The increase of organic $\mathrm{C}$ content in the soil is due to the fertigation using effluent from the biogas reactor that still contains organic material that contributing organic $\mathrm{C}$ to the soil. Table 3 also shows that the organic $\mathrm{C}$ content of the soil was 
Table 3. The Effect of Treatment on Soil Conditions

\begin{tabular}{|c|c|c|c|c|c|c|}
\hline \multirow{2}{*}{ Treatment } & \multicolumn{6}{|c|}{ Parameter } \\
\hline & $\mathrm{pH}$ & C (\%) & $\mathrm{N}(\%)$ & $\mathrm{C} / \mathrm{N}$ & $\mathrm{P}$ tot $(\%)$ & $\mathrm{K}$ tot $(\%)$ \\
\hline TIK1 & 5.13 & 1.67 & 0.16 & 10.44 & 0.011 & 0.029 \\
\hline$($ Criteria*) & Acid & Low & Low & Low & Netral & Netral \\
\hline TIK2 & 5.13 & 1.61 & 0.15 & 10.71 & 0.010 & 0.028 \\
\hline (Criteria*) & Acid & Low & Low & Low & Netral & Netral \\
\hline TIK3 & 5.33 & 1.61 & 0.15 & 10.73 & 0.010 & 0.028 \\
\hline$($ Criteria*) & Acid & Low & Low & Low & Netral & Netral \\
\hline TIK4 & 4.90 & 1.78 & 0.16 & 10.94 & 0.012 & 0.030 \\
\hline$($ Criteria*) & Acid & Low & Low & Low & Netral & Netral \\
\hline $\mathrm{T} 2 \mathrm{~K} 1$ & 4.80 & 1.77 & 0.16 & 11.06 & 0.011 & 0.033 \\
\hline (Criteria*) & Acid & Low & Low & Low & Netral & Netral \\
\hline T2K2 & 5.00 & 1.68 & 0.17 & 10.08 & 0.011 & 0.033 \\
\hline$($ Criteria*) & Acid & Low & Low & Low & Netral & Netral \\
\hline T2K3 & 5.27 & 1.75 & 0.16 & 10.74 & 0.012 & 0.038 \\
\hline (Criteria*) & Acid & Low & Low & Low & Netral & Netral \\
\hline T2K4 & 4.60 & 1.72 & 0.18 & 9.70 & 0.011 & 0.039 \\
\hline (Criteria*) & Acid & Low & Low & Low & Netral & Netral \\
\hline T3K1 & 5.23 & 1.35 & 0.14 & 9.83 & 0.008 & 0.070 \\
\hline (Criteria*) & Acid & Low & Low & Low & Low & High \\
\hline T3K2 & 5.47 & 1.51 & 0.14 & 10.76 & 0.009 & 0.070 \\
\hline (Criteria*) & Acid & Low & Low & Low & Low & High \\
\hline T3K3 & 5.50 & 1.38 & 0.14 & 9.88 & 0.009 & 0.070 \\
\hline$($ Criteria*) & Acid & Low & Low & Low & Low & High \\
\hline T3K4 & 5.40 & 1.50 & 0.15 & 10.18 & 0.008 & 0.070 \\
\hline (Criteria*) & Acid & Low & Low & Low & Low & High \\
\hline T4K1 & 5.30 & 1.64 & 0.17 & 9.80 & 0.011 & 0.051 \\
\hline (Criteria*) & Acid & Low & Low & Low & Netral & High \\
\hline T4K2 & 5.33 & 1.61 & 0.17 & 9.47 & 0.012 & 0.052 \\
\hline$($ Criteria*) & Acid & Low & Low & Low & Netral & High \\
\hline T4K3 & 5.50 & 1.78 & 0.18 & 9.87 & 0.012 & 0.052 \\
\hline (Criteria*) & Acid & Low & Low & Low & Netral & High \\
\hline T4K4 & 5.40 & 1.63 & 0.16 & 10.00 & 0.012 & 0.053 \\
\hline (Criteria*) & Acid & Low & Low & Low & Netral & High \\
\hline
\end{tabular}

Note: *) Based on Chemical Technical Guidelines for Soil, Plants, Water and Fertilizers (SRI, 2005).

still relatively low despite increasing. That is because during the anaerobic digestion process, most of carbon compounds are converted into $\mathrm{CH}_{4}$ and $\mathrm{CO}_{2}$ [21]. During anaerobic digestion about 20-95\% of the carbon $(\mathrm{C})$ in the feedstock are transformed into gaseous $\mathrm{C}$ compounds, depending on type of the feedstocks [22].

Fertigation by using biogas digester effluent also increases nitrogen content of the soil after the experiment. $\mathrm{N}$ total of the soil before treatment is only about $0.14 \%$. After treatment, $\mathrm{N}$ total increased to 0.15 $0.16 \%$ in pakcoy plants, $0.16-0.18 \%$ in water spinach plants, $0.14-0.15 \%$ in tomato plants and $0.16-0.18 \%$ in cucumber plants. Residues of biogas plants are generally rich in NH4+-N [23]. According to Nkoa (2014), when anaerobic digestate is applied to the soil, $\mathrm{NH} 4+$ is absorbed by plant root cells, or adsorbed on soils containing negatively charged particles, or oxidized to NO3- by nitrifying microorganisms [21]. The nitrogen will be absorbed in the soil (non-mobile), so that the total nitrogen content of the soil will increase in a short time. The results of the study also showed that the $\mathrm{C} / \mathrm{N}$ ratio of the soil before treatment was 9.92 . 
After the experiment, the $\mathrm{C} / \mathrm{N}$ ratio of the soil ranged from 10.44-10.94 in pakcoy plants, 9.70-11.06 in water spinach plants, 9.83-10.76 for tomato plants, and 9.4710.00 in cucumber plants. The $\mathrm{C} / \mathrm{N}$ ratio is still relatively low for plant growth. Total phosphorus content in the soil before treatment is around $0.0078 \%$ (relatively low). After the experiment, the total phosphorus content increased to neutral condition using three plants, namely $0.0105 \%-0.0124 \%$ in pakcoy plants, $0.0111 \%-0.0116 \%$ in water spinach plants, and $0.0114 \%-0.0124 \%$ in cucumber plants. The increase is due to the phosphorus contained in the effluent into a phosphorus deposit when applied to the soil. For tomato plants phosphorus content insignificantly change $0.0078 \%-0.0086 \%$. Phosphorus is an essential macroelement, required for plant nutrition. It participates in metabolic processes such as photosynthesis, energy transfer and synthesis and breakdown of carbohydrates. The results also shows that the total potassium in the soil before the experiment was $0.020 \%$ (relatively low). After treatment, total soil potassium increased to $0.028 \%-0.030 \%$ for pakcoy plants, $0.033 \%-0.039 \%$ for water spinach plants, $0.066 \%-0.071 \%$ for tomato plants, and $0.051 \%-0.053 \%$ for cucumber plants. Pakcoy application and water spinach causes a change in total potassium from low to moderate, while cucumber application causes a change in total potassium from low to high condition.

\subsection{EFFECT OF TREATMENT ON REDUCING ENVIRONMENT LOAD}

The effect of plant treatment on reduction of pollutant load are shown in Table 4. It shows that water spinach and pakcoy have a higher potential in reducing COD, nitrogen, phosphorus, and potassium as compared to tomatoes and cucumbers. Reduction of the COD concentration may occur due to phytodegradation mechanism where organics contaminant is broken down through activities of plant metabolic or through plant enzymes $[24,25]$. The microorganisms around the plant roots zone may enhance the degradation process. The roots of water spinach serve as amedium for the microbial growth. Therefore, the organic matter can be effectively removed [26]. Zhang et al. (2014) reported that phosphorus removal by water spinach was mainly through plant absorption mechanism. For nitrogen, the main mechanism for the ammonia and nitrate removal by water spinach were by nitrogen microorganisms comprising of ammonifying bacteria, nitrifying bacteria and denitrifying bacteria[27]. Sa'at and Zaman (2017) reported that phytoremediation using water spinach was able to reduce the COD concentration, nutrients and suspended solid of the aerobic POME up to $80 \%$ of all parameter by the end of 25 days of treatment [28]. Other study also reported that water spinach floating bed for pig farm biogas reactor wastewater treatment showed $99 \%$ of COD and over $90 \%$ removal of total phosphorus, total nitrogen and nitrate within 4 months of growth season [25]. According to Rane et al. (2016), about $76 \%, 87 \%, 34 \%, 63 \%$ and $56 \%$ of BOD, COD, total solid, total nitrogen and total phosphorus reduction on pretreated textile effluent, respectively can achieved and suggested that water spinach as best plant with effective treatment of the effluent [29]. Effendi et al. (2016) reported that water spinach directly absorb ammonium through the roots as a natural fertilizer up to $78.42 \%$, more optimally as compared to that of pakcoy with $52.16 \%$ [30].

Table 4. The effect of plant treatment on the reduction of environment load

\begin{tabular}{|l|c|c|c|c|}
\hline \multirow{2}{*}{ Plant } & \multicolumn{4}{|c|}{ Reduction of environment load } \\
\cline { 2 - 5 } & COD & Nitrogen & Phosphorus & Potassium \\
\hline Pakcoy & $\begin{array}{c}3,09-5,34 \\
(\mathrm{~kg} / \mathrm{ha} / \text { day })\end{array}$ & $\begin{array}{c}1,44-2,75 \\
(\mathrm{~kg} / \mathrm{h} / \text { /day })\end{array}$ & $\begin{array}{c}0,33-0,63 \\
(\mathrm{~kg} / \mathrm{ha} / \text { day })\end{array}$ & $\begin{array}{c}0,24-0,46 \\
(\mathrm{~kg} / \mathrm{ha} / \text { day })\end{array}$ \\
\hline Water & $\begin{array}{c}3.70-5.90 \\
\text { spinach }\end{array}$ & $\begin{array}{c}1,52-2,77 \\
(\mathrm{~kg} / \mathrm{ha} / \mathrm{day})\end{array}$ & $\begin{array}{c}0,35-0,63 \\
(\mathrm{~kg} / \mathrm{ha} / \text { day })\end{array}$ & $\begin{array}{c}0,25-0,46 \\
(\mathrm{~kg} / \mathrm{ha} / \text { day })\end{array}$ \\
\hline Tomato & $\begin{array}{c}3.63-4.60 \\
(\mathrm{~kg} / \mathrm{ha} / \text { day })\end{array}$ & $\begin{array}{c}1,41-2,16 \\
(\mathrm{~kg} / \mathrm{ha} / \text { day })\end{array}$ & $\begin{array}{c}0,32-0,49 \\
(\mathrm{~kg} / \mathrm{ha} / \text { day })\end{array}$ & $\begin{array}{c}0,24-0,36 \\
(\mathrm{~kg} / \mathrm{ha} / \text { day })\end{array}$ \\
\hline Cucumber & $\begin{array}{c}2.44-3.24 \\
(\mathrm{~kg} / \mathrm{ha} / \text { day })\end{array}$ & $\begin{array}{c}1,15-2,08 \\
(\mathrm{~kg} / \mathrm{ha} / \text { day })\end{array}$ & $\begin{array}{c}0,26-0,47 \\
(\mathrm{~kg} / \mathrm{ha} / \text { day })\end{array}$ & $\begin{array}{c}0,19-0,35 \\
(\mathrm{~kg} / \mathrm{ha} / \text { day })\end{array}$ \\
\hline
\end{tabular}

The results also showed that cultivation of organic vegetables every hectare of soil, pakcoy plants with available water $81 \%-100 \%$ (T1K1) were able to decrease in load of $7,47 \%$, water spinach cultivation with water was available $61 \%-80 \%$ (T2K2 ) able to reduce the load by $8,26 \%$, tomato cultivation with available water $41 \%-60 \%$ (T3K3) capable of reducing the load of $6,43 \%$, and cucumber cultivation with available water $81 \%-100 \%$ (T4K2) capable of reducing the load by $4,54 \%$. Scaling up calculation for an industry with a production capacity of 100 tons of cassava per day produces biogas digester effluent with pollution load reaches $71,50 \mathrm{~kg} \mathrm{COD} /$ day, $33,53 \mathrm{~kg}$ $\mathrm{N} /$ day, $7,65 \mathrm{~kg} \mathrm{P} /$ day and $5,61 \mathrm{~kg} \mathrm{~K} /$ day. In order to decrease pollution load totally to $0 \%$, the following options can be taken: (a) cultivation of pakcoy plants, with available soil water $81 \%-100 \%$ (T1K1) on 13,39 ha of land, or (b) water spinach cultivation, with available soil water $61 \%-80 \%$ (T2K2) on 12,11 ha of land, or (c) cultivation of tomato plants, with soil water available a $41 \%-60 \%$ (T3K3) on 15,55 ha of land, or (d) cultivation of cucumber plants, with soil water available $61 \%-80 \%$ (T4K2) on 22,05 ha of land. The best treatment to decreasing pollution load in observation variables $\mathrm{COD}$, nitrogen $(\mathrm{N})$, phosphorus $(\mathrm{P})$, and potassium $(\mathrm{K})$ are indicated by the highest percentage of reduction in pollution load, i.e., effluent utilization for water spinach cultivation at $61 \%-80 \%$ water available 
(T2K2) in one hectare land in the amount of 8,26\% from daily pollution load of biogas reactor effluent.

\section{CONCLUSION}

The conclusions of this research are:

1. Effluent from tapioca wastewater biogas digester still contains organic matter that can be potentially used for fertigation during vegetables cultivation.

2. Water spinach and pakcoy have higher potential in reducing COD, nitrogen, phosphorus, and potassium as compared to tomatoes and cucumbers do.

3. The best treatment to decreasing environment load in terms of COD, nitrogen $(\mathrm{N})$, phosphorus $(\mathrm{P})$, and potassium $(\mathrm{K})$ are indicated by the highest percentage of reduction in environment load, where effluent utilization for water spinach cultivation at $61 \%-80 \%$ soil water available (T2K2) reduce environment load by $8,26 \%$.

\section{REFERENCES}

[1] U. Hasanudin, A. Haryanto, E. Suroso, 2011, Mitigation of Green House Gases Emission in Cassava Mill: Case Study in Lampung, Indonesia Proceeding of International Conference and Exhibition on Sustainable Energy and Advanced Materials (ICE SEAM) International Conference and Exhibition on Sustainable Energy and Advanced Materials (ICE SEAM 2011) (Surakarta, Indonesia: Universitas SebelasMaret) pp 54-60

[2] KLH (Kementerian Lingkungan Hidup Republik Indonesia) 2009 Pedoman Pengelolaan Limbah Industri Pengolahan Tapioka (Jakarta: Asisten Deputi Urusan Pengendalian Pencemaran AgroIndustri, Deputi MENLH Bidang Pengendalian Pencemaran Lingkungan, Kementerian Negara LingkunganHidup R.I)

[3] L. Sun, S. Wan, Z. Yu, Y. Wang, S. Wang, 2012, Anaerobic biological treatment of high strength cassava starch wastewater in a new type up-flow multistage anaerobic reactor Bioresource. Technol.104 280-8

[4] U. Hasanudin, M.E. Kustyawati, D.A. Iryani, A. Haryanto, S. Triyono, 2019, Estimation of energy and organic fertilizer generation from small scale tapioca industrial waste IOP Conf. Ser. Earth Environ. Sci.230 012084

[5] A. Haryanto, D. Cahyani, S. Triyono, F. Murdapa, D. Haryono, 2017, Economic Benefit and Greenhouse Gas Emission Reduction Potential of A Family-Scale Cowdung Anaerobic Biogas Digester, Int. J. Renew. Energy Dev.6 29

[6] A. Haryanto, F. Marotin, S. Triyono, U. Hasanudin, 2017, Developing A Family-Size Biogas-Fueled Electricity Generating System, Int. J. Renew. Energy Dev.6 111

[7] K.K.N. Edith, G. Théophile, K.K. Félix, B.K. Yves, K.K. Martin, K.Y. Francis, T. Kablan, 2013, Improving anaerobic biodigestion of manioc wastewater with human urine as cosubstrate. Int. J. Innov. Appl. Stud.2 335-43

[8] W.N. Schirmer, J.F.T. Jucá, A.R.P. Schuler, S. Holanda, L.L. Jesus, 2014, Methane production in anaerobic digestion of organic waste from Recife (Brazil) landfill: evaluation in refuse of different ages, Braz. J. Chem. Eng.31 373-84

[9] O. Kuczman, M.H.F. Tavares, S.D. Gomes, L.P.C. Guedes, G. Grisotti, 2017, Effects of stirring on cassava effluent treatment in an anaerobic horizontal tubular pilot reactor with support medium. A Review Renew. Sustain. Energy Rev.77 984-9

[10] P.R.F. Rosa, S.C. Santos, I.K. Sakamoto, M.B.A Varesche, E.L. Silva, 2014, The effects of seed sludge and hydraulic retention time on the production of hydrogen from a cassava processing wastewater and glucose mixture in an anaerobic fluidized bed reactor, Int. J. Hydrog. Energy 39 13118-27

[11] W. Wang, L. Xie, J. Chen, G. Luo, Q. Zhou, 2011, Biohydrogen and methane production by co-digestion of cassava stillage and excess sludge under thermophilic condition. Bioresour. Technol.102 3833-9

[12] G. Tchobanoglous, L. Ruppe, H. Leverenz, J. Darby, 2004, Decentralized wastewater management: challenges and opportunities for the twenty-first century. Water Sci. Technol. Water Supply 4 95-102

[13] U. Hasanudin, E. Suroso, T.P. Utomo, B.R. Shivakoti, K. Fujie, 2014, Sustainable Wastewater Treatment in Small Scale Tapioca Factory Proceeding of $9^{\text {th }}$ IWA International Symposium on Waste management Problems in Agroindustries (Kochi, Japan: The International Water Association)

[14] APHA 1999 Standard Methods for the Examination of Water and Wastewater

[15] W.O. Thom, M. Utomo, 1991, Manajemen Laboratorium dan Metode Analisis Tanah dan Tanaman (Bandar Lampung, Indonesia: Universitas Lampung) 
[16] Y. Wang, X. Zhang, C. Huang, 2009, Spatial variability of soil total nitrogen and soil total phosphorus under different land uses in a small watershed on the Loess Plateau. China Geoderma 150 141-9

[17] L.K. Sharma, A.A. Zaeen, S.K. Bali, J.D. Dwyer, 2018, Improving Nitrogen and Phosphorus Efficiency for Optimal Plant Growth and Yield New Visions in Plant Science ed. Ö Çelik (InTech).

[18] I.R.C. Araujo, S.D. Gomes, T.U. Tonello, S.D. Lucas, A.G. Mari, R.J. de Vargas, 2018, Methane Production from Cassava Starch Wastewater in Packed-Bed Reactor and Continuous Flow Eng. Agríc. 38 270-6

[19] J. Manuel, 2014, Nutrient Pollution: A Persistent Threat to Waterways Environ. Health Perspect.122 A304-9

[20] R.P. Pareek, N. Pareek, 2019, Agricultural Microbiology (Scientific Publishers)

[21] R. Nkoa, 2014, Agricultural benefits and environmental risks of soil fertilization with anaerobic digestates: a review Agron. Sustain. Dev.34 473-92

[22] K. Möller, 2015, Effects of anaerobic digestion on soil carbon and nitrogen turnover, $\mathrm{N}$ emissions, and soil biological activity - A review Agron. Sustain. Dev.35 1021-41

[23] R. Gutser, Th. Ebertseder, A. Weber, M. Schraml, U. Schmidhalter, 2005, Short-term and residual availability of nitrogen after long-term application of organic fertilizers on arable land $\mathbf{J}$. Plant Nutr. Soil Sci.168 439-46

[24] I.A.W. Al-Baldawi, S.R.S. Abdullah, F. Suja, N. Anuar, I. Mushrifah, 2013, Comparative performance of free surface and sub-surface flow systems in the phytoremediation of hydrocarbons using Scirpusgrossus. J. Environ. Manage. 130 324-30
[25] X. Yu, Z. Li, S. Zhao, K. Li, 2013, Biomass Accumulation and Water Purification of Water Spinach Planted on Water Surface by Floating Beds for Treating Biogas Slurry. J. Environ. Prot. 04 1230-5

[26] J.H. Lee, 2013, An overview of phytoremediation as a potentially promising technology for environmental pollution control. Biotechnol. Bioprocess Eng.18 431-9

[27] Q. hang, V. Achal, Y. Xu, W.N. Xiang, 2014, Aquaculture wastewater quality improvement by water spinach (Ipomoea aquatica Forsskal) floating bed and ecological benefit assessment in ecological agriculture district Aquac. Eng.60 4855

[28] S.K. Sa'at, N.Q. Zaman, 2017, Suitability of Ipomoea Aquatica for the Treatment of Effluent from Palm Oil Mill. J. Built Environ. Technol. Eng.2 39-44

[29] N.R. Rane, S.M. Patil, V.V. Chandanshive, S.K. Kadam, R.V. Khandare, J.P. Jadhav, S.P. Govindwar, 2016, Ipomoea hederifolia rooted soil bed and Ipomoea aquatica rhizofiltration coupled phytoreactors for efficient treatment of textile wastewater Water Res.96 1-11

[30] H. Effendi, B.A. Utomo, G.M. Darmawangsa, R.E. Karo-Karo, 2015, Fitore mediasi limbah budidaya ikan lele (Clarias Sp.) dengan kangkung (Ipomoea aquatica) dan pakcoy (Brassica rapa Chinensis) dalam sistem resirkulasi Ecolab 9 80-92. 